\title{
Synthesis and thermal decomposition study of dysprosium trifluoroacetate
}

\author{
Opata, Y. A.; Grivel, J.-C.
}

Published in:

Journal of Analytical and Applied Pyrolysis

Link to article, DOI:

10.1016/j.jaap.2018.03.018

Publication date:

2018

Document Version

Peer reviewed version

Link back to DTU Orbit

Citation (APA):

Opata, Y. A., \& Grivel, J-C. (2018). Synthesis and thermal decomposition study of dysprosium trifluoroacetate. Journal of Analytical and Applied Pyrolysis, 132, 40-46. https://doi.org/10.1016/j.jaap.2018.03.018

\section{General rights}

Copyright and moral rights for the publications made accessible in the public portal are retained by the authors and/or other copyright owners and it is a condition of accessing publications that users recognise and abide by the legal requirements associated with these rights.

- Users may download and print one copy of any publication from the public portal for the purpose of private study or research.

- You may not further distribute the material or use it for any profit-making activity or commercial gain

- You may freely distribute the URL identifying the publication in the public portal

If you believe that this document breaches copyright please contact us providing details, and we will remove access to the work immediately and investigate your claim. 


\section{Accepted Manuscript}

Title: Synthesis and Thermal decomposition study of Dysprosium Trifluoroacetate

Authors: Y.A. Opata, J.-C. Grivel

PII: $\quad$ S0165-2370(17)30907-5

DOI: $\quad$ https://doi.org/10.1016/j.jaap.2018.03.018

Reference: $\quad$ JAAP 4292

To appear in: J. Anal. Appl. Pyrolysis

Received date: $\quad 11-10-2017$

Revised date: $\quad 13-3-2018$

Accepted date: $\quad 18-3-2018$

Please cite this article as: Y.A.Opata, J.-C.Grivel, Synthesis and Thermal decomposition study of Dysprosium Trifluoroacetate, Journal of Analytical and Applied Pyrolysis https://doi.org/10.1016/j.jaap.2018.03.018

This is a PDF file of an unedited manuscript that has been accepted for publication. As a service to our customers we are providing this early version of the manuscript. The manuscript will undergo copyediting, typesetting, and review of the resulting proof before it is published in its final form. Please note that during the production process errors may be discovered which could affect the content, and all legal disclaimers that apply to the journal pertain. 


\title{
Synthesis and Thermal decomposition study of Dysprosium Trifluoroacetate
}

\author{
Y. A. Opata* and J-C. Grivel
}

Department of Energy Conversion and Storage, Technical university of Denmark

Frederiksborgvej 399, 4000 Roskilde, Denmark

${ }^{*}$ Corresponding author: Tel.: +45 46775899

E-mail address: yaop@dtu.dk, yuriopata@gmail.com (Yuri A. Opata)

\section{Highlights}

- The thermal decomposition process of the dysprosium trifluoroacetate has been investigated.

- The presence of some carbon is verified in the system after decomposition stage.

- Formation of the $\mathrm{DyF}_{3}$ and DyOF phases are confirmed by $\mathrm{TG}$ and $\mathrm{x}$-ray diffraction data.

- Analysis of the gases released allowed following the entire decomposition process.

\begin{abstract}
A study of the thermal decomposition process of dysprosium trifluoroacetate hydrate under flowing argon is presented. Thermogravimetry, differential thermal analysis, evolved gas analysis and ex-situ x-ray diffraction techniques have been employed in the investigation. Three main stages were identified: dehydration, decomposition and phase transformation from $\mathrm{DyF}_{3}$ to DyFO. The dehydration takes place in 2 steps and the decomposition also occurs in two stages. The observed residual mass demonstrated a discrepancy with the calculated value for $\mathrm{DyF}_{3}$ formation. Observations on quenched samples at temperatures just above the decomposition step and at $828^{\circ} \mathrm{C}$ showed a variation in the sample color, being dark in the first case and rather bright at the higher quenching temperature. Based on this fact, we concluded that some carbon remains in the
\end{abstract}


sample up to $800^{\circ} \mathrm{C}$. With the temperature reaching $1300^{\circ} \mathrm{C}$, a plateau is observed in the TG signal, which mass value agrees with the formation of DyFO as verified by the ex-situ $x$-ray data of quenched powder. Using the FTIR and MS spectra of released gases during the process and the TG data, a decomposition scheme is suggested.

Keywords: Thermal decomposition, dysprosium trifluoroacetate, TG, DTA, FTIR and mass spectrometry.

\section{Introduction}

Trifluoroacetate (TFA) precursors are being widely used for the manufacture of high performance hightemperature superconducting (HTS) coated conductors and thin film, processed through the chemical solution decomposition (CSD) method [1]-[7]. The manufacture of HTS coated conductors beneficiates from a prior knowledge of the (metal) TFA thermal decomposition mechanism, by allowing the determination and optimization of the involved pyrolysis and reaction processes. Therefore, an increasing number of studies on the thermal decomposition of TFA complexes have been made in the past years [8]-[10]. Earlier, Rillings had investigated the thermal decomposition of the $\mathrm{Pr}, \mathrm{Sm}$ and $\mathrm{Er}$ trifluoroacetate compounds in air and vacuum, wherever the formation of $\mathrm{LnF}_{3}$ and $\mathrm{LnOF}(\mathrm{Ln}=\mathrm{Pr}, \mathrm{Sm}$ and $\mathrm{Er})$ was ascertained [11]. IR measurements of the volatile products revealed the presence of $\mathrm{CO}, \mathrm{CO}_{2}, \mathrm{CF}_{3} \mathrm{COF}$ and $\left(\mathrm{CF}_{3} \mathrm{CO}\right)_{2} \mathrm{O}$. Based on these results the following decomposition scheme was proposed: $\mathrm{Ln}\left(\mathrm{CF}_{3} \mathrm{COO}\right)_{3}->\mathrm{LnF}_{3}+\left(\mathrm{CF}_{3} \mathrm{CO}\right)_{2}+\mathrm{CO}_{2}+\mathrm{CO}$. A similar study carried out under static air, covering all lanthanide trifluoroacetate complexes, was reported in [12]. Through TG and DTA experiments the $\mathrm{LnF}_{3}$ formation as final solid residue (now with $\mathrm{Ln}=\mathrm{La}-\mathrm{Lu}$, except Pm), at temperatures between $300^{\circ} \mathrm{C}$ and $550^{\circ} \mathrm{C}$, was also confirmed.

The thermal behavior of $\mathrm{Dy}(\mathrm{TFA})$, which is used as a precursor in the preparation of $\mathrm{DyBa}_{2} \mathrm{Cu}_{3} \mathrm{O}_{7-\delta}$ superconducting thin films and coated conductors [1] still deserves additional studies. In particular, the exact nature of the gas species released during the decomposition process is not clear, because the use of static air, as used in [12], results in combustion of organic materials. This kind of strongly exothermic reaction induces local overheating in the sample that can potentially disturb the reaction course mechanism and, in particular, its kinetics. Furthermore, the manufacture of rare-earth cuprate HTS coated conductors imposes the use of low 
oxygen partial pressure [13], thus, thermal decomposition studies in Ar are important to complete previous work made in air as well as an excellent starting point for more specific investigations with precisely controlled low $\mathrm{pO}_{2}$ conditions. With this in view, the present work reports on a thermal decomposition study of $\mathrm{Dy}\left(\mathrm{CF}_{3} \mathrm{COO}\right)_{3}$ under flowing argon gas, based on simultaneous TG-DTA, while the nature of the gases released during the process were investigated using FTIR and MS spectroscopic methods and phase changes were followed by means of insitu high temperature x-ray measurements.

\section{Material and methods}

Dysprosium trifluoroacetate, $\mathrm{Dy}\left(\mathrm{CF}_{3} \mathrm{COO}\right)_{3}$, was synthesized from dysprosium acetate tetrahydrate, Dy $\left(\mathrm{CH}_{3} \mathrm{COO}\right)_{3} \cdot 4 \mathrm{H}_{2} \mathrm{O}$, supplied by Alfa Aesar $99.9 \%$ purity-metal basis $(\mathrm{MB})$, following a procedure similar to that applied for the preparation of $\mathrm{DyBa}_{2} \mathrm{Cu}_{3} \mathrm{O}_{7-\delta}$ precursor solutions [1]. The same MB purity is expected for the synthesized $\mathrm{Dy}\left(\mathrm{CF}_{3} \mathrm{COO}\right)_{3}$, since no other metallic cations have been involved in the process. Approximately $2 \mathrm{~g}$ of $\mathrm{Dy}\left(\mathrm{CH}_{3} \mathrm{COO}\right)_{3} \cdot 4 \mathrm{H}_{2} \mathrm{O}$ were mixed with $3.5 \mathrm{ml}$ trifluoroacetic acid $(99.9 \%$ from Alfa Aesar) and $10 \mathrm{ml}$ deionized water. The solution was being stirred on a hot plate during 2 hours at $50^{\circ} \mathrm{C}$ and, after reaction, was heated at about $100^{\circ} \mathrm{C}$ to evaporate the excess solvent. TG and DTA measurements were carried out in a NETZSCH model STA 449C simultaneous TG-DTA, using Ar gas flow (with $0.5 \mathrm{ppm}$ residual $\mathrm{O}_{2}$ content). Sample masses of $20 \mathrm{mg}$ were used for this purpose. The powder was loaded into uncovered alumina crucibles. The samples were heated from room temperature to $1450^{\circ} \mathrm{C}$ at $2 \mathrm{~K} / \mathrm{min}$ with a gas flow of $50 \mathrm{ml} / \mathrm{min}$. The signals were afterwards corrected by subtracting a base line curve, obtained on an empty crucible with the same heating profile. FTIR spectra of the evolved gases resulting from decomposition were recorded simultaneously with the TG-DTA measurements using a BRUKER, model TENSOR27 spectrometer connected to the TG-DTA equipment by a hot line maintained at $200^{\circ} \mathrm{C}$. Mass spectrometry was also used to identify the released gases, employing a NETZSCH - QMS 403 D Aëolos mass spectrometer linked by a quartz glass capillary, heated to $200^{\circ} \mathrm{C}$, to a NETZSCH - STA 409CD thermobalance. The mass spectra were collected and analyzed in the 1$299 \mathrm{~m} / \mathrm{z}$ range. The conditions of sample mass, temperature, heating rate and gas flow for the MS experiments were the same used in the TG-DTA. Ex-situ x-ray measurements, carried out on quenched samples, were 
employed to investigate the crystallographic phase. A Rigaku diffractometer was used to collect the $\mathrm{x}$-ray patterns from $2 \theta=25^{\circ}$ to $70^{\circ}$ with a scan speed of $1 \% \mathrm{~min}$.

\section{Results and discussion}

The XRD pattern and FTIR spectrum of the as-prepared sample powder are displayed in Figure 1(a) and (b), respectively. The XRD data show that the compound is well crystallized and confirm that the sample consists of the $\mathrm{Dy}\left(\mathrm{CF}_{3} \mathrm{COO}\right)_{3} \cdot 3 \mathrm{H}_{2} \mathrm{O}$ phase, by comparison with the reference data (JCPD files number 052-0724). Furthermore, the absorption bands observed in the FTIR spectrum match those reported in [14]-[16] for RE-TFA salts, $\mathrm{RE}=\mathrm{Y}, \mathrm{Sm}, \mathrm{Eu}, \mathrm{Er}$ and $\mathrm{Yb}$, which are expected to exhibit similar absorption bands.

Figure 2 shows the thermal analysis results obtained under $50 \mathrm{ml} / \mathrm{min}$ argon gas flow. The first two steps in the TG curve (peaks at $86^{\circ} \mathrm{C}$ and $125^{\circ} \mathrm{C}$ in the DTG and DTA traces) are associated to the loss of water, as confirmed by the solid residue and evolved gas FTIR measurements, showed in Figure 3 and 5(b) respectively. In the latter, broad peaks in the $3750-3000 \mathrm{~cm}^{-1}$ region, assigned to $\mathrm{vOH}$ vibrations [15], are observed in the asprepared powder, whereas the FTIR spectrum obtained from the powder quenched at $200^{\circ} \mathrm{C}$ does not present similar peaks, evidencing the complete release of water. From the TG trace the amount of disassociated water during these first stages can be estimated as $1.62 \pm 0.02$ and $1.10 \pm 0.05$ water molecules. A dehydration process taking place in two or more steps was also found for other RE(TFA) compounds, with quantities of dissociated water being observed between 1 and 3.7 molecules of $\mathrm{H}_{2} \mathrm{O}$ per formula unit $[8,12,17]$. Upon further heating, a small endothermic peak (at $239^{\circ} \mathrm{C}$ ) is observed, accompanied by some mass change. A similar peak was reported in [11] and [12], where it was assigned to a "solution effect" involving the anhydrous precursor dissolved in some water of hydration. A similar behavior of the DTA and TG traces was also reported in [18], but in that case it was assumed to be due to a partial decarboxylation of the anhydrous compound. According to the mass spectra data (see Figure 6), carbon dioxide fragments, among other precursors, are detected at around $233^{\circ} \mathrm{C}$, indicating that the endothermic peak might be related to a decarboxylation process. At $280^{\circ} \mathrm{C}$ the $\mathrm{Dy}\left(\mathrm{CF}_{3} \mathrm{COO}\right)_{3}$ anhydrous phase exhibits a large mass loss, related to its decomposition, achieving a plateau with 
a mass of $41.9 \%$ of the initial sample mass, at around $350^{\circ} \mathrm{C}$. Based on previous studies on trifluoroacetate compounds $[8,11,12,17], \mathrm{DyF}_{3}$ would be expected to form after the decomposition of the TFA ligands. However the observed sample mass is still higher than the one calculated for the formation of $\mathrm{DyF}_{3}(39.8 \%)$ see dashed horizontal lines in Figure 2. A possible reason is that some carbon remains in the sample (about 0.9 carbon atoms per $\mathrm{DyF}_{3}$ molecule on average would account for the observed sample mass). By quenching the sample at $405^{\circ} \mathrm{C}$, one can observe a dark coloring (see inset picture in Figure 2), whereas a sample quenched at $828^{\circ} \mathrm{C}$ - the temperature at which the observed sample mass matches with that calculated for $\mathrm{DyF}_{3}-$ a lighter color is observed. This supports the assumption that elemental carbon was left in the sample at $405^{\circ} \mathrm{C}$, before being oxidized and released in the form of $\mathrm{CO}_{2}$ or $\mathrm{CO}$ at higher temperature. Finally, close to the maximum temperature, the TG curve reaches a plateau, with mass of $35.3 \%$. Such value agrees with the formation of DyFO (35.8\%).

FTIR results, acquired from samples quenched at different temperatures, are presented in Figure 3 . The spectrum of the as-grown sample from Figure $1(b)$ is displayed again for comparison purpose. The heating rate employed was the same as that used for the TG measurements. A strong well-defined triplet absorption band in the region $1723-1619 \mathrm{~cm}^{-1}$, associated to $\mathrm{CO}_{2}$ vibrations, suggests chelating-bridging TFA for the as-prepared sample [15]. On the other hand, the spectrum acquired at $200^{\circ} \mathrm{C}$ shows a single broad peak at $1640 \mathrm{~cm}^{-1}$ in the same range, which might be due a different bonding of the trifluoroacetate ligands [15, 16]. Another characteristic peak from TFA $[9,14,15,19]$ is also observed in the region $1473-1487$ and is related to $v \mathrm{SO}_{2}$. A doublet at 1204-1143 due to $v \mathrm{C}-\mathrm{F}$ and $v \mathrm{C}-\mathrm{O}$ vibrations and bands in the $855-609 \mathrm{~cm}^{-1}$ region, supposedly from $\delta \mathrm{sFCF}_{2}, \delta \mathrm{asCF}_{3}$ and $\delta \mathrm{asFCF}_{2}[15,19]$ are also observable. The complete TFA ligands decomposition is verified in the spectrum recorded at $405^{\circ} \mathrm{C}$, where no characteristic peaks are observed.

Figure 4 displays the $\mathrm{x}$-ray patterns recorded from solid residue obtained after quenching the samples from the indicated temperatures. The heating rate and gas conditions employed here were the same as in the TG experiments. Using the powder diffraction file PDF2 database, the following phases were identified: orthorhombic DyF 3 (JCPD files number 032-0352) and rhombohedral DyFO (JCPD files number 019-0437), for the powder quenched at $405^{\circ} \mathrm{C}$ and $1280^{\circ} \mathrm{C}$, respectively. The apparent peaks observed in the XRD pattern from 
sample quenched at $1280^{\circ} \mathrm{C}$ on both sides of the DyOF reflection at $2 \theta=28.6^{\circ}$ are artefacts resulting from the subtraction of the sample-holder and the low intensity signal from the powder sample. For the sample treated up to $826^{\circ} \mathrm{C}$ we note the presence of $\mathrm{DyF}_{3}$ with some reflections from rhombohedral and cubic DyFO (JCPD files number 033-0524). These results are in good agreement with the mass evolution data observed from the TG curve, where $\mathrm{DyF}_{3}$ is expected to be found up to $830^{\circ} \mathrm{C}$ and $\mathrm{DyFO}$ at higher temperatures.

Figure 5(a) presents the FTIR evolved gas analysis spectra, acquired during the Dy(TFA) heating, around the main mass loss in Figure 2. Gas species are first detected at $256^{\circ} \mathrm{C}$, with the observation of small amounts of $\mathrm{CO}_{2}\left(2353\right.$ and $\left.2328 \mathrm{~cm}^{-1}\right)$ and $\mathrm{CO}\left(2176\right.$ and $\left.2115 \mathrm{~cm}^{-1}\right)$ and absorption bands at 1829, 1784, 1213 and 1120 $\mathrm{cm}^{-1}$ from $\mathrm{CF}_{3} \mathrm{COF},\left(\mathrm{CF}_{3} \mathrm{CO}\right)_{2} \mathrm{O}$ and $\mathrm{CF}_{3} \mathrm{COOH}$. With the increase in temperature, $\mathrm{COF}_{2}, \mathrm{CF}_{3} \mathrm{COF}_{2}\left(\mathrm{CF}_{3} \mathrm{CO}\right)_{2} \mathrm{O}$ emissions are also identified, as well as a minor peak at $1155 \mathrm{~cm}^{-1}$ from $\mathrm{CHF}_{3}$. All the identified absorption bands are summarized in Table 1. Similar characteristic absorption bands were also observed during the thermal decomposition of $\mathrm{Y}\left(\mathrm{CF}_{3} \mathrm{COO}\right)_{3}$ [17] and $\mathrm{Cu}\left(\mathrm{CF}_{3} \mathrm{COO}\right)_{2}$ [10]. Figure 5(b) shows the collected FTIR spectra of detected gases around $89^{\circ} \mathrm{C}$ and $131^{\circ} \mathrm{C}$, which further confirm the release of water [20] observed in the Figure 2 at similar temperatures.

From mass spectroscopy experiments (Figure 6) it was possible to confirm the interpretation of the FTIR data. One can notice on Figure 6(a) that the main fragments are related to $\left[\mathrm{CO}_{2}\right]^{+}(\mathrm{m} / \mathrm{z}=44)$, which follows the DTG curve rather well, and $[\mathrm{F}]^{+}(\mathrm{m} / \mathrm{z}=19) . \mathrm{CF}_{3} \mathrm{COOH}, \mathrm{COF}_{2},\left(\mathrm{CF}_{3} \mathrm{CO}\right)_{2} \mathrm{O}$ and $\mathrm{CF}_{3} \mathrm{CFO}$ species were evidenced by $[\mathrm{COOH}]^{+}(\mathrm{m} / \mathrm{z}=45),(\mathrm{m} / \mathrm{z}=66)\left[\mathrm{COF}_{2}\right]^{+},(\mathrm{m} / \mathrm{z}=97)\left[\mathrm{CF}_{3} \mathrm{CO}\right]^{+}$and $(\mathrm{m} / \mathrm{z}=47)[\mathrm{COF}]^{+}$observation, respectively, whereas peaks $(\mathrm{m} / \mathrm{z}=31)[\mathrm{CF}]^{+},(\mathrm{m} / \mathrm{z}=50)\left[\mathrm{CF}_{2}\right]^{+}$and $(\mathrm{m} / \mathrm{z}=69)\left[\mathrm{CF}_{3}\right]^{+}$might result from the contribution of all of them.

The peaks $\mathrm{m} / \mathrm{z}=12,16$ and 22 are also from $\mathrm{CO}_{2}$ fragmentation and present an evolution similar to that of $\mathrm{m} / \mathrm{z}=44$. Two other peaks that were detected with non-negligible intensity are $\mathrm{m} / \mathrm{z}=15$ and 43 , which could be ascribed to fragments of $\mathrm{CH}_{3} \mathrm{COO}$ and $\mathrm{CH}_{3} \mathrm{COCH}_{3}$ [21, 22]. These might originate from the decomposition of remnants unreacted starting material $\mathrm{Dy}(\mathrm{CH} 3 \mathrm{COO})_{3}$. Minor intensities from $\left[\mathrm{CF}_{2}\right]^{++}(\mathrm{m} / \mathrm{z}=25)$ and $\left[\mathrm{CF}_{3} \mathrm{CFO}^{+}\right.$ $(\mathrm{m} / \mathrm{z}=116)$ are also observed around the main peak of Figure 2, the latter being associated to the $\mathrm{CF}_{3} \mathrm{COF}$ compound. A look at Figure 6 (b) reveals the presence of the $\left[\mathrm{CHF}_{2}\right]^{+}(\mathrm{m} / \mathrm{z}=51)$ ion, which can be due to either 
$\mathrm{CF}_{3} \mathrm{COOH}$ or $\mathrm{CHF}_{3}$. At around $270^{\circ} \mathrm{C}$ its evolution is similar to that of $\mathrm{m} / \mathrm{z}=45$, however it presents a secondary peak at $315^{\circ} \mathrm{C}$, not observed for $[\mathrm{COF}]^{+}$. The $\mathrm{FTIR}$ results indicate the formation of $\mathrm{CHF}_{3}$ at elevated temperature $\left(\sim 290^{\circ} \mathrm{C}\right)$, which suggests that this peak is a contribution from both $\mathrm{CF}_{3} \mathrm{COOH}$ and $\mathrm{CHF}_{3}$ compounds. The data in Figure 6 reveals furthermore that the decomposition process occurs in two stages, as also reported for other trifluoroacetate compounds [9, 23]. At around $233^{\circ} \mathrm{C}$, peaks in the signals $\mathrm{m} / \mathrm{z}=12,16$, $17,18,22,44$ and 45 are observed. These fragments are associated to the release of $\mathrm{CO}_{2}, \mathrm{H}_{2} \mathrm{O}$ and $\mathrm{CF}_{3} \mathrm{COOH}_{\text {, }}$ as already mentioned. Therefore, the endothermic peak observed in the DTA signal (Figure 2) at around $239^{\circ} \mathrm{C}$ might actually be attributed to a decarboxylation process rather than to a boiling effect. In addition, the detected $\mathrm{CF}_{3} \mathrm{COOH}$ appears as a result of the reaction between $\left(\mathrm{CF}_{3} \mathrm{CO}\right)_{2} \mathrm{O}$ and water as describe below in the text.

Based on the presented results, the following set of reactions is proposed. First, as indicated by equations (1-1), (1-2) and (2), dehydration of the Dy(TFA) takes place, as clearly observed in the inset of Figure 6, where the $\left[\mathrm{H}_{2} \mathrm{O}\right]^{+}(\mathrm{m} / \mathrm{z}=18)$ and $[\mathrm{OH}]^{+}(\mathrm{m} / \mathrm{z}=17)$ ion emissions were observed. Then TFA decomposition takes place, resulting in the $\mathrm{DyF}_{3}+\mathrm{C},\left(\mathrm{CF}_{3} \mathrm{CO}\right)_{2} \mathrm{O}, \mathrm{CO}$ and $\mathrm{O}_{2}$ formation. Herein, carbon remains in the sample after $\mathrm{Dy}\left(\mathrm{CF}_{3} \mathrm{COO}\right)_{3}$ decomposition, as suggested by the TG results as well as by the dark color of the powder. In the case where all TFA ligands have been removed, the expected reaction $[8,11,12,17]$ would be as indicated by equation (3).

$$
\begin{aligned}
& \mathrm{Dy}\left(\mathrm{CF}_{3} \mathrm{COO}\right)_{3} \cdot 2.7 \mathrm{H}_{2} \mathrm{O} \rightarrow \mathrm{Dy}\left(\mathrm{CF}_{3} \mathrm{COO}\right)_{3} \cdot 1.6 \mathrm{H}_{2} \mathrm{O}+1.1 \mathrm{H}_{2} \mathrm{O} \\
& \mathrm{Dy}\left(\mathrm{CF}_{3} \mathrm{COO}\right)_{3} \cdot 1.6 \mathrm{H}_{2} \mathrm{O} \rightarrow \mathrm{Dy}\left(\mathrm{CF}_{3} \mathrm{COO}\right)_{3}+1.6 \mathrm{H}_{2} \mathrm{O} \\
& \mathrm{Dy}\left(\mathrm{CF}_{3} \mathrm{COO}\right)_{3} \rightarrow \mathrm{DyF}_{3}+\mathrm{C}+\left(\mathrm{CF}_{3} \mathrm{CO}\right)_{2} \mathrm{O}+\mathrm{CO}+\mathrm{O}_{2} \\
& \operatorname{Dy}\left(\mathrm{CF}_{3} \mathrm{COO}\right)_{3}->\mathrm{DyF}_{3}+\left(\mathrm{CF}_{3} \mathrm{CO}\right)_{2} \mathrm{O}+\mathrm{CO}+\mathrm{CO}_{2}
\end{aligned}
$$

As some $\mathrm{CF}_{3} \mathrm{COOH}$ was detected both by FTIR and MS, it is suggested that some water vapor was trapped in the sample and reacted with $\left(\mathrm{CF}_{3} \mathrm{CO}\right)_{2} \mathrm{O}$, forming trifluoroacetic acid following [8, 17], according to reaction (4). This $\mathrm{CF}_{3} \mathrm{COOH}$ later decomposes into $\mathrm{CF}_{2}, \mathrm{HF}$ and $\mathrm{CO}_{2}[10,17]$, as suggested by the $\left[\mathrm{CF}_{2}\right]^{++}(\mathrm{m} / \mathrm{z}=25)$ and $\left[\mathrm{CF}_{2}\right]^{+}(\mathrm{m} / \mathrm{z}=50),[\mathrm{F}]^{+}(\mathrm{m} / \mathrm{z}=19)$ and $\left[\mathrm{CO}_{2}\right]^{+}(\mathrm{m} / \mathrm{z}=44)$ detection in the MS data. 


$$
\begin{gathered}
\left(\mathrm{CF}_{3} \mathrm{CO}\right)_{2} \mathrm{O}+\mathrm{H}_{2} \mathrm{O} \rightarrow 2 \mathrm{CF}_{3} \mathrm{COOH} \\
\mathrm{CF}_{3} \mathrm{COOH} \rightarrow \mathrm{CF}_{2}+\mathrm{HF}+\mathrm{CO}_{2} \\
\mathrm{CF}_{2}+\mathrm{HF} \rightarrow \mathrm{CHF}_{3}
\end{gathered}
$$

As already mentioned above, the observation of $\mathrm{CHF}_{3}$ by FTIR and MS could be the result of a side reaction between $\mathrm{CF}_{2}$ and $\mathrm{HF}$, resulting in a minor detection [9, 17]. Finally, once all the available water has been used for the $\mathrm{CF}_{3} \mathrm{COOH}$ forming reaction, it is probable that $\left(\mathrm{CF}_{3} \mathrm{CO}\right)_{2} \mathrm{O}$ decomposes as indicated in $[8,11,12,17]$, according to:

$$
\left(\mathrm{CF}_{3} \mathrm{CO}\right)_{2} \mathrm{O} \rightarrow \mathrm{CF}_{3} \mathrm{COF}+\mathrm{COF}_{2}+\mathrm{CO}
$$

\section{Conclusions}

The thermal decomposition of dysprosium trifluoroacetate hydrate, as well as the evolved gas species released during the process, was investigated by means of TG-DTA, FTIR/MS and ex-situ x-ray diffraction. Two massloss steps were observed in the first stage of heating up to $195^{\circ} \mathrm{C}$, and could be assigned to two dehydration processes, wherein the loss of around 2.7 water molecules take place. Further heating results in a small endothermic peak at $239^{\circ} \mathrm{C}$, an event that can be ascribed, based on the mass spectroscopy results, to a decarboxylation process. The decomposition process is then characterized by an intense exothermic peak centered at $280^{\circ} \mathrm{C}$, accompanied by a $49 \%$ mass reduction of the sample. FTIR and MS spectra analyzes of released volatile compounds enable the identification of $\mathrm{CF}_{3} \mathrm{COF},\left(\mathrm{CF}_{3} \mathrm{CO}\right)_{2} \mathrm{O}, \mathrm{CHF}_{3}, \mathrm{CF}_{3} \mathrm{COOH}, \mathrm{COF}_{2}, \mathrm{CO}_{2}$ and CO. Previous investigations about the decomposition process of $M(T F A)$ precursors ( $M$ = lanthanide elements) have demonstrated the formation of $\mathrm{MF}_{3}$ phases after the decomposition process [11, 12]. However, in our case, the resulting residual sample mass after decomposition showed a value higher $(42.0 \%)$ than the calculated one (39.8\%). Pictures of quenched samples, heated under similar conditions as in the TG experiments, revealed a dark coloration of the sample quenched at $405^{\circ} \mathrm{C}$ (end of the decomposition process) and a brighter color in that heated up to $828^{\circ} \mathrm{C}$. Therefore, we believe that some carbon remained in the sample. At $1300^{\circ} \mathrm{C}$, the 
sample mass reached a plateau, with a value corresponding to the formation of DyFO formation. Analyzes of $x-$ ray diffraction patterns, collected from quenched samples, revealed the formation of $\mathrm{DyF}_{3}$ up to $830^{\circ} \mathrm{C}$ and $\mathrm{DyFO}$ phase for elevate temperatures. Based on all obtained results, a decomposition scheme was established. Further work is in progress to study and understand the influence of oxidating and/or water saturated atmospheres on the thermal decomposition of this compound, conditions that will be closer to those used for the manufacture of RE123 superconducting thin films.

\section{Acknowledgements}

This work was supported by the Brazilian program Science without borders - Proc. Number BEX 13491/13-0. 


\section{References}

[1] Y. A. Opata, A. C. Wulff, J. O. B. Hansen, Y. Zhao and J-C. Grivel. Superconducting $\mathrm{Dy}_{1-x}\left(\mathrm{Gd}, \mathrm{Yb}_{\times} \mathrm{Ba}_{2} \mathrm{Cu}_{3} \mathrm{O}_{7-\delta}\right.$ thin films made by Chemical Solution Deposition. IEEE Transactions on Applied Superconductivity, 26(3) (2016) 7500705 (5pp).

[2] Y. Zhao, W. Wu, X. Tang, N. H. Andersen, Z. Han and J-C. Grivel. Epitaxial growth of $\mathrm{YBa}_{2} \mathrm{Cu}_{3} \mathrm{O}_{7-x}$ films on $\mathrm{Ce}_{0.9} \mathrm{La}_{0.1} \mathrm{O}_{2-y}$ buffered yttria-stabilized zirconia substrates by an all-chemical-solution route. CrystEngComm, 16 (2014) 4369-4372.

[3] K. De Keukeleere, P. Cayado, A. Meledin, F. Vallès, J. De Roo, H. Rijckaert, G. Pollefeyt, E. Bruneel, A. Palau, M. Coll, S. Ricart, G. Van Tendeloo, T. Puig, X. Obradors and I. Van Driessche. Superconducting $\mathrm{YBa}_{2} \mathrm{Cu}_{3} \mathrm{O}_{7-\delta}$ Nanocomposites Using Preformed $\mathrm{ZrO}_{2}$ Nanocrystals: Growth Mechanisms and Vortex Pinning Properties. Advanced Electronic Materials, 2 (2016) 1600161 (9pp).

[4] P. Abellán , F. Sandiumenge, M-J. Casanove, M. Gibert, A. Palau, T. Puig and X. Obradors. Interaction between solution derived $\mathrm{BaZrO}_{3}$ nanodot interfacial templates and $\mathrm{YBa}_{2} \mathrm{Cu}_{3} \mathrm{O}_{7}$ films leading to enhanced critical currents. Acta Materialia 59 (2011) 2075-2082.

[5] Y. Xu, H-L. Suo, Y. Zhao, J-C. Grivel and M. Liu. Jc Enhancement by La-Al-O Doping in Y-Ba-Cu-O Films Both in Self-Field and Under Magnetic Field. IEEE Transactions on Applied Superconductivity, 26(3) (2016) $6602804(4 \mathrm{pp})$.

[6] T. Qureishy, Y. Zhao, Y. Xu, J. I. Vestgården, T. H. Johansen, J-C. Grivel, H. Suo, P. Mikheenko. Magnetic flux channelling in YBa2Cu3O7- $\delta$ films grown by a chemical solution deposition technique on vicinal and nonvicinal substrates. Advanced Materials Letters, 8 (2017) 1204-1210.

[7] P. Garcés, M. Coll, H. Castro, T. Puig and X. Obradors. Preparation of YBCO-BYTO and YBCO-BZO nanostructured superconducting films by chemical method. Journal of Physics. Conference Series, 786 (2017) 012017 (5pp). 
[8] H. Eloussifi, J. Farjas, P. Roura, J. Camps, M. Dammak, S. Ricart, T. Puig and X. Obradors. Evolution of yttrium trifluoroacetate during thermal decomposition. Journal of Thermal Analysis and Calorimetry, 108 (2012) 589-596.

[9] J. Farjas, J. Camps, P. Roura, S. Ricart, T. Puig and X. Obradors. The thermal decomposition of barium trifluoroacetate. Thermochimica Acta, 544 (2012) 77-83.

[10] M. Mosiadz, K. L. Juda, S. C. Hopkins, J. Soloducho and B. A. Glowacki. An in-depth in situ IR study of the thermal decomposition of copper trifluoroacetate hydrate. Journal of Fluorine Chemistry, 135 (2012) 59-67.

[11] K. W. Rillings and J. E. Roberts. A thermal study of the trifluoroacetates and pentafluoropropionates of praseodymium, samarium and erbium. Thermochimica Acta, 10 (1974) 285-298.

[12] Y. Yoshimura and K. Ohara. Thermochemical studies on the lanthanoid complexes of trifluoroacetic acid. Journal of alloys and compounds, 408-412 (2006) 573-576.

[13] R. Feenstra, T. B. Lindemer, J. D. Budai and M. D. Galloway. Effect of pressure on the synthesis of $\mathrm{YBa}_{2} \mathrm{Cu}_{3} \mathrm{O}_{7-\mathrm{x}}$ thin films by post-deposited annealing. Journal of Applied Physics, 69 (1991) 6569-6585.

[14] V. Y. Kavun, T. A. Kaidalova, V. I. Kostin, E. S. Panin and B. N. Chernyshov. X-ray-diffraction and IR spectroscopic study of crystallohydrates trifluoroacetates of samarium, europium, erbium and ytterbium. Koordinatsionnaya Khimiya, 10 (1984) 1502-1504.

[15] S. Mishra, L. G. Hubert-Pfalzgraf, S. Daniele, M. Rolland, E. Jeanneau and B. Jouguet. Thermal dehydration of $\mathrm{Y}(\mathrm{TFA})_{3}\left(\mathrm{H}_{2} \mathrm{O}\right)_{3}$ : Synthesis and molecular structures of $\left[\mathrm{Y}\left(\mu, \eta^{1}: \eta^{1}-\mathrm{TFA}\right)_{3}(\mathrm{THF})\left(\mathrm{H}_{2} \mathrm{O}\right)_{1 \infty}\right] \cdot \mathrm{THF}$ and $\left[\mathrm{Y}_{4}\left(\mu_{3^{-}}\right.\right.$ $\left.\mathrm{OH})_{4}\left(\mu, \eta^{1}: \eta^{1}-\mathrm{TFA}\right)_{6}\left(\eta^{1}-\mathrm{TFA}\right)\left(\eta^{2}-\mathrm{TFA}\right)(\mathrm{THF})_{3}(\mathrm{DMSO})\left(\mathrm{H}_{2} \mathrm{O}\right)\right] \cdot 6 \mathrm{THF}(\mathrm{TFA}=$ trifluoroacetate $)$. Inorganic Chemistry Communications, 12(2) (2009) 97-100.

[16] J. Zhang, S. Morlens, L. G. Hubert-Pfalzgraf and D. Luneau. Synthesis, Characterization and Molecular Structures of Yttrium Trifluoroacetate Complexes with O- and N-Donors: Complexation vs. Hydrolysis. European Journal of Inorganic Chemistry, (2005) 3928-3935. 
[17] M. Mosiadz, K. L. Juda, S. C. Hopkins, J. Soloducho and B. A. Glowacki. An in-depth in situ IR study of the thermal decomposition of yttrium trifluoroacetate hydrate. Journal of Thermal Analysis and Calorimetry, 107 (2012) 681-691.

[18] N. P. Sokolova, L. A. Sheludyakova, V. I. Lisoivan, V. P. Fadeeva and S. V. Larionov. Synthesis and Study of Gadolinium(III), Terbium(III), and Dysprosium(III) Trifluoroacetate Trihydrates. Russian Journal of General Chemistry, 67 (1997) 1327-1330.

[19] C. Rüssel. A pyrolytic route to fluoride glasses. I. Preparation and thermal decomposition of metal trifluoroacetates. Journal of Non-Crystalline Solids, 152 (1993) 161-166.

[20] http://webbook.nist.gov/chemistry/form-ser.html.

[21] J. Farjas, J. Camps, P. Roura, S. Ricart, T. Puig and X. Obradors. Thermoanalytical study of the formation mechanism of yttria from yttrium acetate. Thermochimica Acta, 521 (2011) 84-89.

[22] T. Arii, T. Taguchi, Ak. Kishi, M. Ogawa, Y. Sawada. Thermal decomposition of cerium(III) acetate studied with samplecontrolled thermogravimetric-mass spectrometry (SCTG—MS). J. Eur. Ceram. Soc. 22 (2002) 22832289.

[23] P. Roura, J. Farjas, H. Eloussifi, L. Carreras, S. Ricart, T. Puig and X. Obradors. Thermal analysis of metal organic precursors for functional oxide preparation: Thin films versus powders. Thermochimica Acta, 601 (2015) $1-8$.

[24] D. M. Jollie and P. G. Harrison. An in situ IR study of the thermal decomposition of trifluoroacetic acid. Journal of the Chemical Society, Perkin Transactions 2, (1997) 1571-1575.

[25] R. E. Kagarise. Infrared Spectrum of Trifluoroacetic Acid Vapor. The Journal of Chemical Physics, 27 (1957) 519-522.

[26] N. Fuson and M-L. Josien. Infrared and Raman Spectroscopy Studies of Light and Heavy Trifluoroacetic Acids. The Journal of Chemical Physics, 20 (1952) 1627-1634. 
[27] C. V. Berney. Spectroscopy of $\mathrm{CF}_{3} \mathrm{COZ}$ compounds-IV: Vibrational spectrum of trifluoroacetyl fluoride. Spectrochimica Acta Part A: Molecular Spectroscopy, 27 (1971) 663-672.

[28] R. L. Redington. Matrix-isolation spectra of ${ }^{18} \mathrm{O}$-substituted trifluoroacetic acid monomers and vibrational assignments for related $\mathrm{CF}_{3}$-containing molecules. Spectrochimica Acta Part A: Molecular Spectroscopy, 31 (1975) 1699-1705.

[29] K. Kim and W. T. King. Integrated infrared intensities and atomic polar tensors in fluoroform. The Journal of Chemical Physics, 73 (1980) 5591-5597. 
Figure 1 - (a) XRD pattern of the as-prepared sample powder recorded at room temperature. (b) FTIR spectrum of the same sample.

Figure 2 - Double plotting of TG (left) and DTA (right) obtained from heating the sample up to $1450^{\circ} \mathrm{C}$ at 2 $\mathrm{K} / \mathrm{min}$ rate in $\mathrm{Ar}$ gas flow. Horizontal dashed lines denote the expected residual mass for the formation of: $\operatorname{Dy}\left(\mathrm{CF}_{3} \mathrm{COO}\right)_{3} \cdot 2.7 \mathrm{H}_{2} \mathrm{O}(100 \%) ; \mathrm{Dy}\left(\mathrm{CF}_{3} \mathrm{COO}\right)_{3} \cdot 1.1 \mathrm{H}_{2} \mathrm{O}(94.7 \%) ; \quad \operatorname{Dy}\left(\mathrm{CF}_{3} \mathrm{COO}\right)_{3}(91.0 \%) ; \mathrm{DyF}_{3}+0.9 \mathrm{C}(42.0 \%) ;$ $\mathrm{DyF}_{3}(39.8 \%)$; and DyFO (35.8\%). The inset picture shows the quenched samples at $405^{\circ} \mathrm{C}$ (left) and $828^{\circ} \mathrm{C}$ (right).

Figure 3 - FTIR spectra obtained from as-prepared $\mathrm{Dy}(\mathrm{FTA})_{3}$ powder and also from the solid residue resulting from heated and quenched samples at $200^{\circ} \mathrm{C}$ and $405^{\circ} \mathrm{C}$. The employed heating profile was the same as used for the TG experiment.

Figure 4 - XRD diffractograms collected from quenched powder at $405^{\circ} \mathrm{C}, 826^{\circ} \mathrm{C}$ and $1280^{\circ} \mathrm{C}$. The broad intensity background around $27^{\circ}-35^{\circ}$ and $40^{\circ}-47^{\circ}$, observed only for the two lower temperatures spectra, is due the sample holder signal. Data obtained for the sample quenched at $1280^{\circ} \mathrm{C}$ was multiplied by a factor of 2 for better visualization. The identified crystallographic phases are indicated in the figure. The samples were heated employing the same parameters used for the TG-DTA experiments.

Figure 5 - FTIR spectra of gases released from $\mathrm{Dy}(\mathrm{TFA})_{3} \cdot 2.7 \mathrm{H}_{2} \mathrm{O}$ during decomposition. The data were recorded simultaneously with the TG measurement, carried out in dry Ar gas flow. The curves are offset for a better visualization. (a) spectra recorded from the temperature region around the decomposition process. Dashed lines point out the center of the band positions, indicated by the respective wavenumber in $\mathrm{cm}^{-1}$. (b) evolved gas spectra detected at around $89^{\circ} \mathrm{C}$ and $131^{\circ} \mathrm{C}$, where only absorption bands from water are observed [20].

Figure 6 - (a) and (b) mass spectrometer data from simultaneous TG-MS experiment. The dashed line indicates the DTG trace (with negative value upwards), while solid lines show the detected ions from Dy(TFA) decomposition. The results refer to the main mass loss region of the TG experiment. The inset in frame (a) 
shows the TG (solid line) and DTG (dashed line) curves as well the mass detection related to $\mathrm{H}_{2} \mathrm{O}(\mathrm{m} / \mathrm{z}=17$ and 18) and $F(m / z=19)$.

Figure 1.
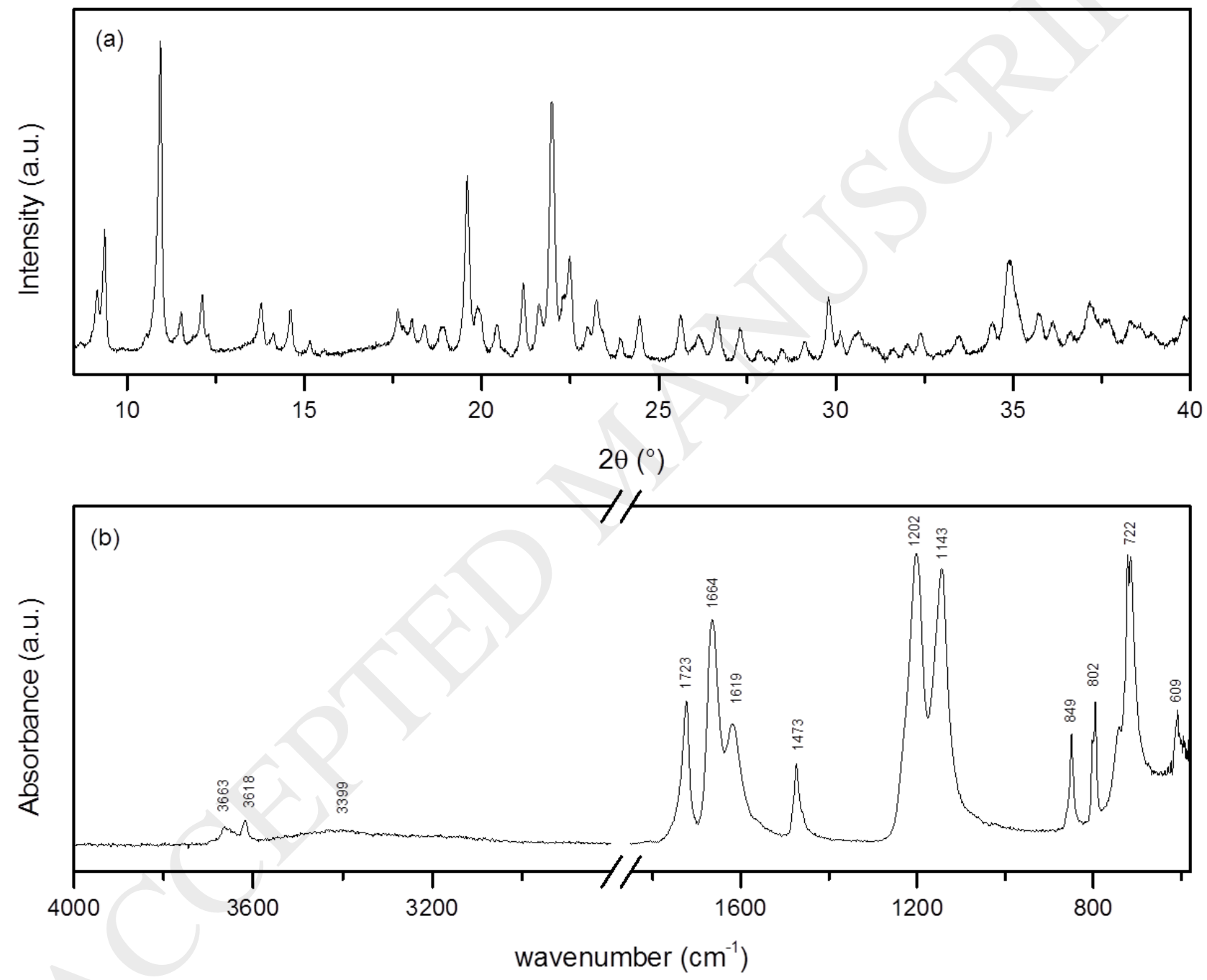
Figure 2.

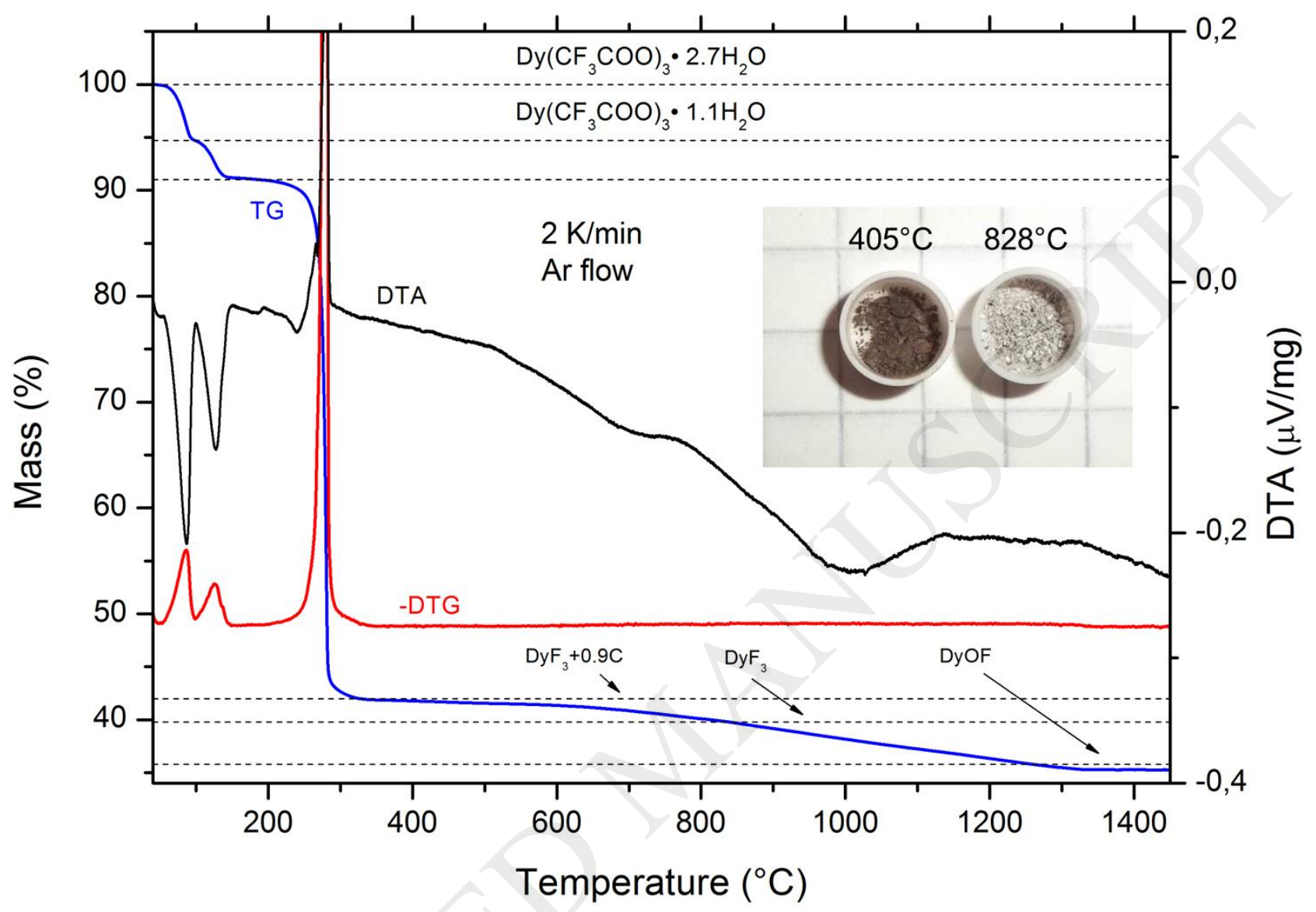


Figure 3.

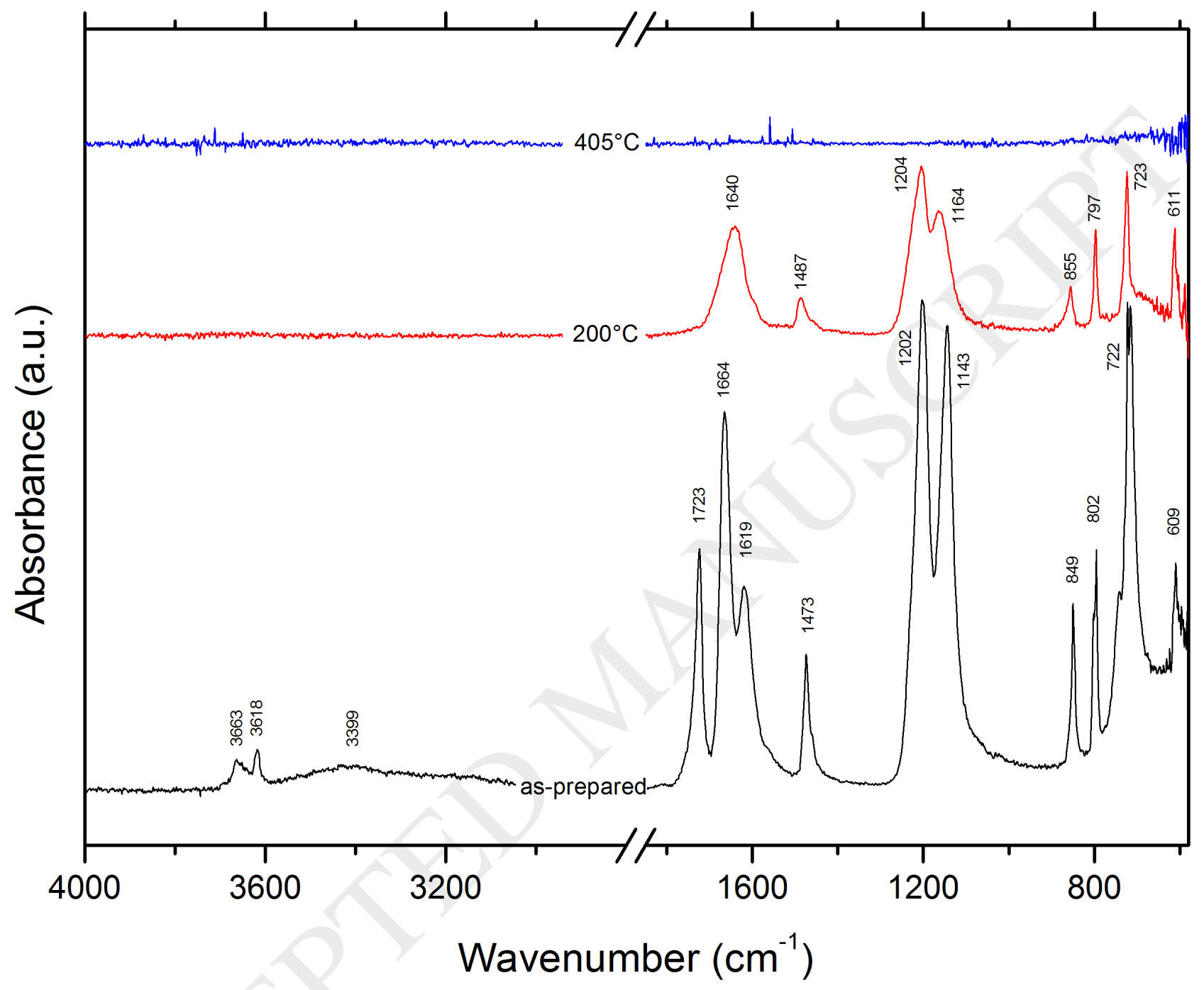


Figure 4.

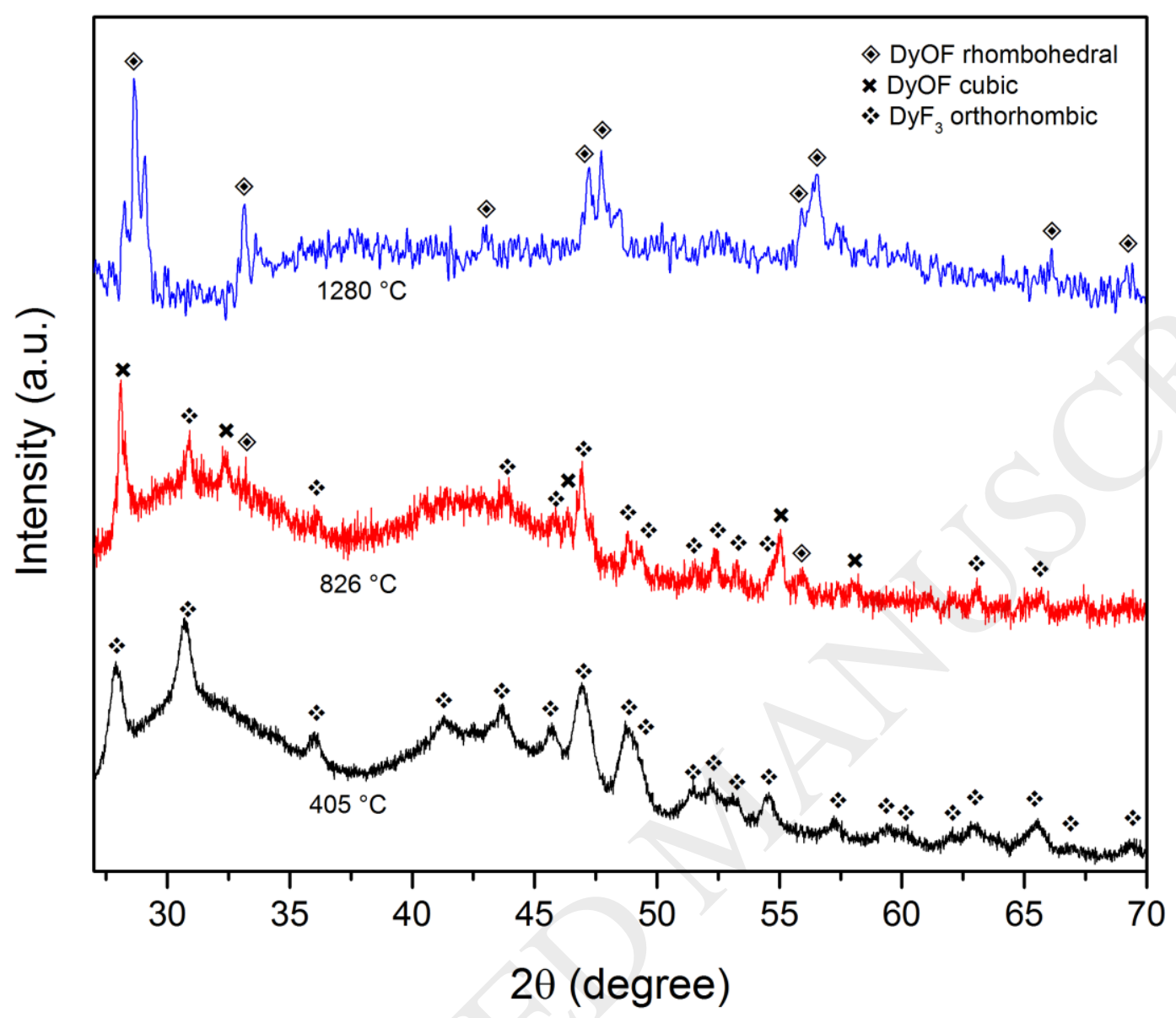


Figure 5.
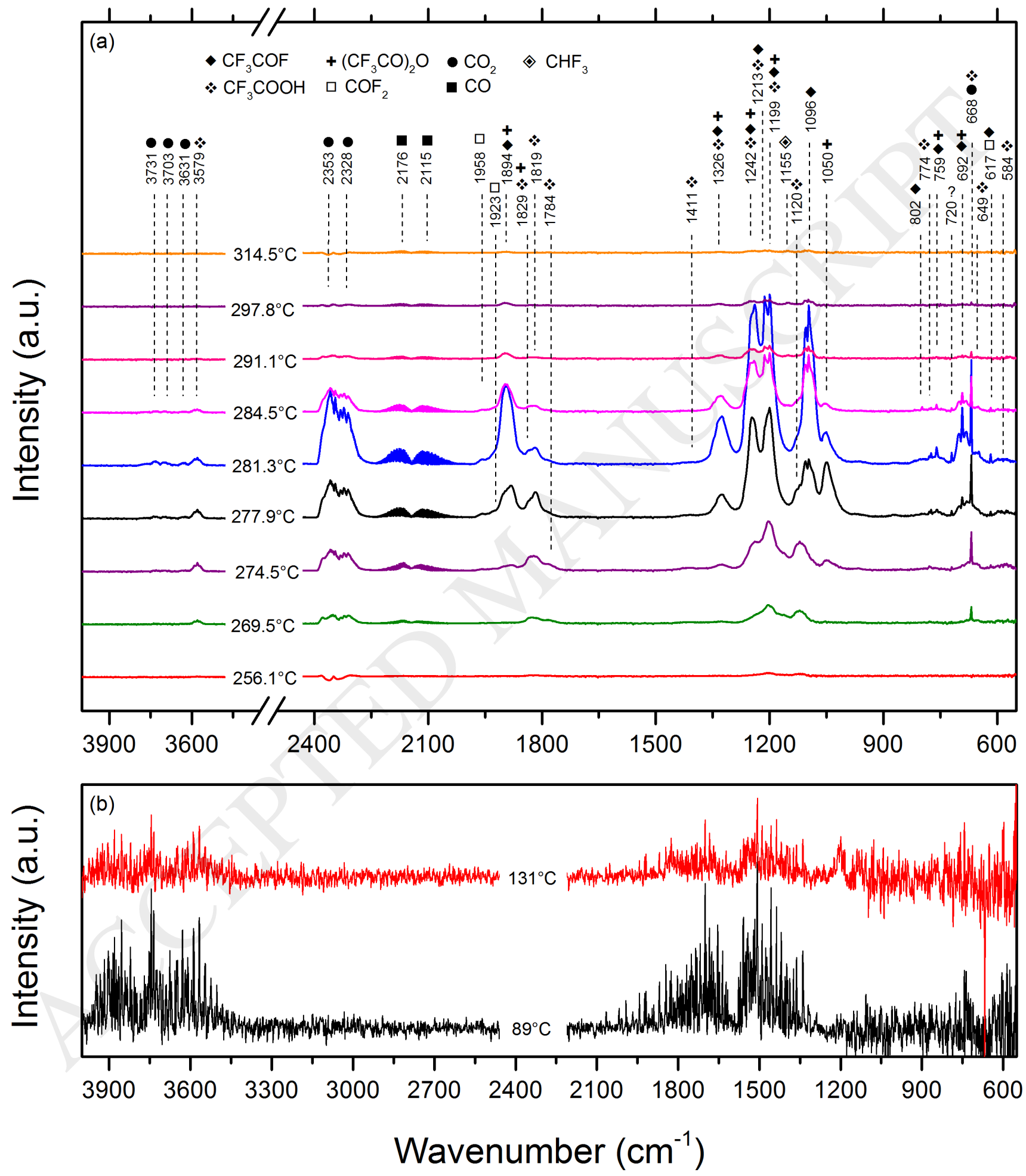
Figure 6.
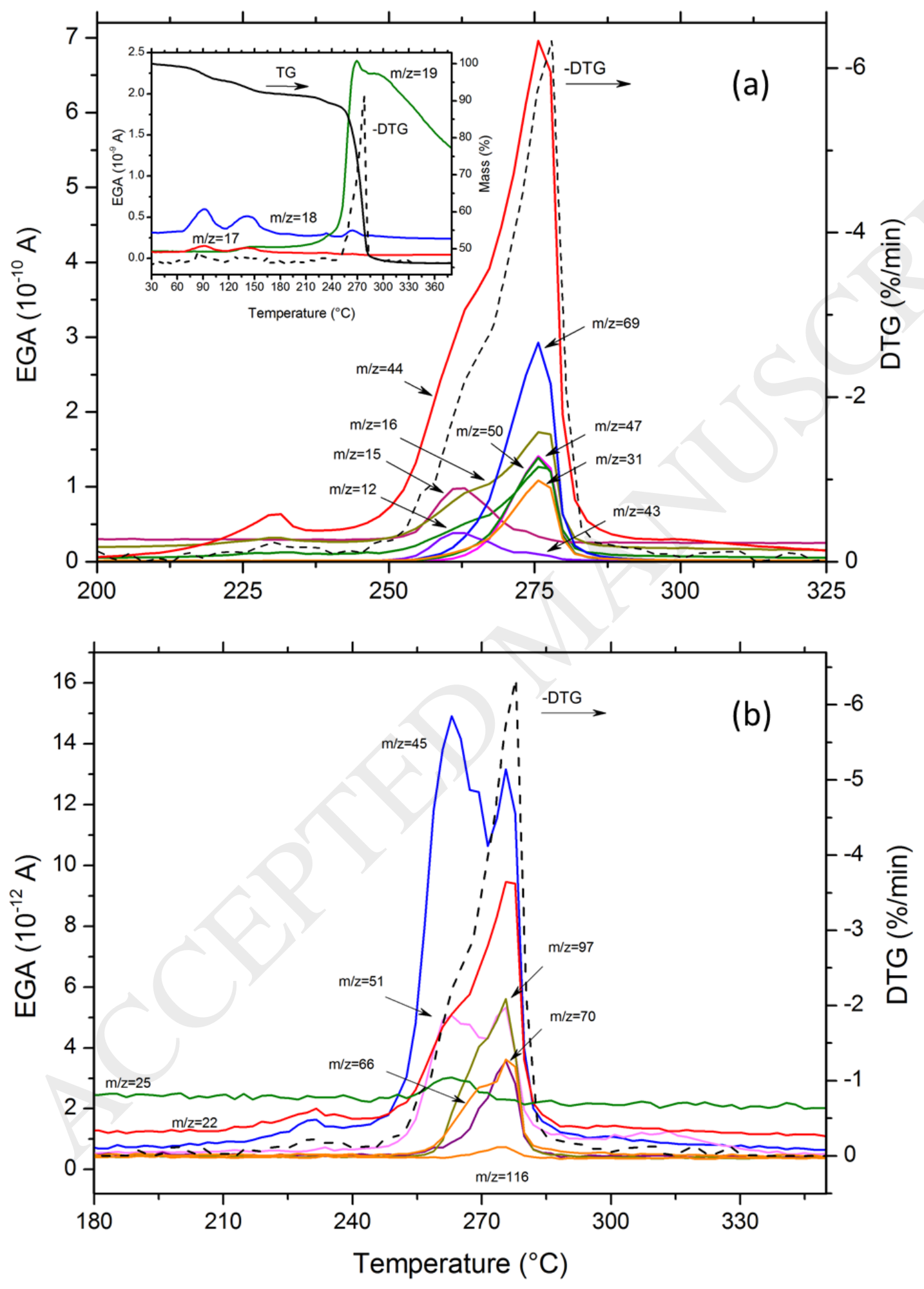
Table 1 - Observed absorption bands from FTIR data, acquired in the range $4000-550 \mathrm{~cm}^{-1}$. The assigned species and description is also presented.

\begin{tabular}{|c|c|c|c|}
\hline $\begin{array}{l}\text { Observed Peak } \\
\text { wavenumber }\left(\mathrm{cm}^{-1}\right)\end{array}$ & Species & Assignment & Reference \\
\hline 3731 & \multirow{3}{*}{$\mathrm{CO}_{2}$} & \multirow{3}{*}{$\mathrm{C}=\mathrm{O}$} & \multirow{3}{*}[17,24]{} \\
\hline 3703 & & & \\
\hline 3631 & & & \\
\hline 3579 & $\mathrm{CF}_{3} \mathrm{COOH}$ & $\mathrm{O}-\mathrm{H}$ str. & {$[17,26]$} \\
\hline 2353 & \multirow[t]{2}{*}{$\mathrm{CO}_{2}$} & \multirow{2}{*}{$\mathrm{C}=\mathrm{O}$ asym. str. } & \multirow[t]{2}{*}[17,24]{} \\
\hline 2328 & & & \\
\hline 2176 & \multirow[t]{2}{*}{$\mathrm{CO}$} & \multirow[t]{2}{*}{$\mathrm{C} \equiv \mathrm{O}$} & \multirow[t]{2}{*}[17,24]{} \\
\hline 2115 & & & \\
\hline 1958 & $\mathrm{CF}_{2} \mathrm{O}$ & $\mathrm{C}=\mathrm{O}$ str. & {$[17,24]$} \\
\hline 1923 & $\mathrm{CF}_{2} \mathrm{O}$ & $\mathrm{C}=\mathrm{O}$ str. & {$[17,24]$} \\
\hline 1894 & $\begin{array}{l}\left(\mathrm{CF}_{3} \mathrm{CO}\right)_{2} \mathrm{O} \\
\mathrm{CF}_{3} \mathrm{COF}\end{array}$ & $\mathrm{C}=\mathrm{O}$ str. & {$[17,24,27,28]$} \\
\hline 1829 & $\begin{array}{l}\mathrm{CF}_{3} \mathrm{COOH} \\
\left(\mathrm{CF}_{3} \mathrm{CO}\right)_{2} \mathrm{O}\end{array}$ & $\mathrm{C}=\mathrm{O}$ str. & {$[17,26]$} \\
\hline 1819 & $\mathrm{CF}_{3} \mathrm{COOH}$ & $\mathrm{C}=\mathrm{O}$ str. & [24] \\
\hline 1784 & $\mathrm{CF}_{3} \mathrm{COOH}$ & $\mathrm{C}=\mathrm{O}$ str. & {$[25,26]$} \\
\hline 1411 & $\mathrm{CF}_{3} \mathrm{COOH}$ & C-O str. & [17] \\
\hline 1326 & $\begin{array}{l}\left(\mathrm{CF}_{3} \mathrm{CO}\right)_{2} \mathrm{O} \\
\mathrm{CF}_{3} \mathrm{COF} \\
\mathrm{CF}_{3} \mathrm{COOH}\end{array}$ & C-F asym. str. & {$[17,25,27]$} \\
\hline
\end{tabular}




\begin{tabular}{|c|c|c|c|}
\hline 1242 & $\begin{array}{l}\left(\mathrm{CF}_{3} \mathrm{CO}\right)_{2} \mathrm{O} \\
\mathrm{CF}_{3} \mathrm{COF} \\
\mathrm{CF}_{3} \mathrm{COOH}\end{array}$ & C-F asym. str. & {$[25,27,28]$} \\
\hline 1213 & $\begin{array}{l}\mathrm{CF}_{3} \mathrm{COF} \\
\mathrm{CF}_{3} \mathrm{COOH}\end{array}$ & $\begin{array}{l}\text { FCF str. } \\
\text { C-F str. }\end{array}$ & {$[24,27]$} \\
\hline 1199 & $\begin{array}{l}\mathrm{CF}_{3} \mathrm{COOH} \\
\mathrm{CF}_{3} \mathrm{COF} \\
\left(\mathrm{CF}_{3} \mathrm{CO}\right)_{2} \mathrm{O}\end{array}$ & $\begin{array}{l}\text { C-F sym. str. } \\
\text { C-C str. }\end{array}$ & {$[24,27,29]$} \\
\hline 1155 & $\mathrm{CHF}_{3}$ & C-F str. & {$[17,24]$} \\
\hline 1120 & $\mathrm{CF}_{3} \mathrm{COOH}$ & O-H ip. def. & [17] \\
\hline 1096 & $\mathrm{CF}_{3} \mathrm{COF}$ & C-F str. & {$[17,24,28]$} \\
\hline 1050 & $\left(\mathrm{CF}_{3} \mathrm{CO}\right)_{2} \mathrm{O}$ & C-F str. & [17] \\
\hline 802 & $\mathrm{CF}_{3} \mathrm{COF}$ & C-C str. & {$[27,28]$} \\
\hline 774 & $\mathrm{CF}_{3} \mathrm{COOH}$ & C-C ip. def. & {$[17,26]$} \\
\hline 759 & $\begin{array}{l}\left(\mathrm{CF}_{3} \mathrm{CO}\right)_{2} \mathrm{O} \\
\mathrm{CF}_{3} \mathrm{COF}\end{array}$ & C-F def. & {$[17,27,28]$} \\
\hline 720 & unknown & unknown & \\
\hline 692 & $\begin{array}{l}\mathrm{CF}_{3} \mathrm{COF} \\
\left(\mathrm{CF}_{3} \mathrm{CO}\right)_{2} \mathrm{O}\end{array}$ & $\begin{array}{l}\text { C-F def } \\
\mathrm{C}=\mathrm{O} \text { def. }\end{array}$ & {$[17,24,27]$} \\
\hline 668 & $\begin{array}{l}\mathrm{CF}_{3} \mathrm{COOH} \\
\mathrm{CO}_{2}\end{array}$ & $\mathrm{C}=\mathrm{O}$ def. & {$[17,24]$} \\
\hline 649 & $\mathrm{CF}_{3} \mathrm{COOH}$ & $\mathrm{C}=\mathrm{O}$ def. & [17] \\
\hline 617 & $\mathrm{COF}_{2}, \mathrm{CF}_{3} \mathrm{COF}$ & $\mathrm{C}=\mathrm{O}$ def. & {$[17,24]$} \\
\hline 584 & $\mathrm{CF}_{3} \mathrm{COOH}$ & C-F ip. sym. def. & [17] \\
\hline
\end{tabular}

str.=stretching; def.=deformation; ip.=in-plane; sym.=symmetric; asym.=asymmetric . 